\title{
THE BUSINESS OF MIGRATORY DIVORCE IN NEVADA
}

\author{
Frank W. Ingram* and G. A. Barzard
}

Divorce in Nevada, like all social phenomena, is in part a product of the history and geography of the state, and consequently, before proceeding to a discussion of the subject of this article, it might be well to give a few descriptive facts about Nevadx.

In area, this state is over 110,000 square miles. Located largely in the American plateau and desert region, it presented real hardships to those Argonauts seeking to rush westward in the early '50's in quest of Mother Lode gold, and the occasional trails and streams of that early period usually mark those pioneers' efforts to establish whatever semblance of civil order and law that then existed. In the Census of $x 860$ 6,857 persons are reported in the then western part of the territory of Utah, now Nevada. It may be assumed that the heavy preponderance of this population was masculine, for in 1880 the ratio was 207 men to each 100 women; in 1910, 197 men to each 100 women. Even in the 1930 Census, with a population of 91,058 , the state's ratio was 1 \&o men to each 100 women, although the national ratio in this last census year was 102 men to each roo. women, the previous nacional ratio favoring men having apparently been overcome by the improved immigration restrictions. Nevada has therefore been a man's'country, engaged in those industrial occupations requiring man power, as distinguished from the older communities of the eastern seaboard from whose progeny it sprang.

The first reported divorce in what is now Nevada occurred in those cow trail days before courts of law were established. It appears from the chronicles of the day that one $\mathrm{K} . . . . .$. , seeking his fortune in the West during the carly years, was proceeding along the Emigrant Trail near the town of Dayton, which lay below 2 stage station and small settlement, then known as Devil's Gate. K......., a widower, was accompanied by a daughter of the age of 14 years. Being uncertain of the camp opportunities for his covered wagon train, $\mathrm{K}$........ decided to recon-

- Member of the Nevada and California Bars. State Director, National Recovery Administration; State Director, National Emergency Council. Industrial Commissioner, Nevada, 1920-1926; City Attorney, Sparks, Nevada, 1926-1932; private practice, Reno, Nevada, 1933-.

+ Member of the Nevada Bar. Assistant Attorney for Compliance, National Recovery Administration, for Nevada. District Attorney, Storey County, Nevada, 1917-r923; District. Judge, Furst District, 19231931; private practice, Reno, Nevada, $2932-$ 
noiter ahead to insure pasture for his oxen. At the stage station a Mrs. C....... of matronly proportions and of good repute agreed to chaperone the young lady during her father's absence, which was expected to be of several days' duration.

Shortly after the departure of the father, there appeared a gay young Lothario with small reputation and no visible means of support acceptable even to the trail standards of that early day. With much gallantry and flattery he soon convinced the young girl that with him the romantic conquest of the West would be preferable and could be accomplished without the hardships of an agricultural future or continued resort to ox-power for transportation. Upon her consent to accompany him, he quickly gathered several of his friends, and arming themselves and securing mounts of known travel speed, they proceeded on the trail westward, taking care to avoid any meeting with the father. The father, upon his return, finding his daughter embarked upon a questionable venture, enlisted the support of some of the more reliable and conservative people of this station, as well as that of several men in his own train, secured good saddle horses, and proceeded in pursuit.

After several days of hard riding, the father overtook his daughter and her contractor per verba de praesenti whom he convinced should accept his daughter's reaffirmation of filial obligation and renunciation of her newly-admitted marital status. Some threat of force of arms was required to maintain this decree until the father could get his daughter over the Sierras to the West.

The record does not disclose whether or not the daughter admitted prior marriage upon arrival in California.

In 186r, shortly after the beginning of the Civil War, a territorial governor was installed, and with him a set of administrative officers. A territorial court was established and a set of civil ordinances adopted, largely copied from those of the State of California, whose organic act had been approved in $1850^{2}$ It was then that the marriage and divorce legislation ${ }^{2}$ was adopted which modified the English common law, then incorporated in the territorial law with the community property law of Mexican origin.

Possibly not from any sense of gallantry, but rather from an acquisitiveness stimulated by the ten-to-one ratio of marriageable females to embryonic statesmen, the male population, to whom the franchise was committed, proceeded to incorporate in the divorce statute all the grounds of divorce known to a cosmopolite legislature. Seven were enumerated, embracing moral lapses, economic omissions, and that misplaced marital confidence termed cruelty: These seemed to serve all domestic needs when administered with such judicial elasticity as equitable courts and liberal Western jurists could evolve.

No great concern or interest in Nevada divorce law was cvidenced in other states and little question of comity entered the situation until nearly half a century had clapsed. It was in Ig00 that public interest was aroused by a noble lord of England

\footnotetext{
${ }^{2}$ Act of Sepr. 9, 1850,9 Stat. 452 .
}

Nev. Stat $886 \mathrm{x}$, p. 94 
who had aiquired a taste for new matrimonial adventure but was encumbered with a faithful wife. The procedure of Henry VIII no longer being in vogue, he responded either to the advice of counsel or the urging of his inamorata, and appeared in Nevada for the time required to establish a residence there and to start life anew in the Western United States.' A divorce suit was instituted, but the faithful wife, failing his Lordship in an approval of the plan by appearing in the Nevada action, remained at home. His Lordship, yearning again for his ancestral surroundings, returned to England with his newly-asquired wife. The faithful wife objected to a second lady's assuming her prerogatives and refused to accept even a blue-ribboned decree of the Sovereign State of Nevada. Instead she promptly divorced her noble spouse in England. His Lordship was thereupon indicted and taken into custody by the Gentleman Usher of the Black Rod for trial by the House of Lords. That House, after many a session devoted to legal battles and the accumulation of a mountain of evidence and law, decided that his Lordship should cool his ardor in the Tower for bigamy. "Thus ended his Lordship's Odyssey.

The discussion in pulpit and press of this cause cellebre centered the attention of others, both lawyers and laymen, upon the possibilities of securing relief from marital situations which prior to that time had seemed insurmountable for one reason or another. This instituted the "zush" which gradually developed to its present proportions which have been maintained at a fairly constant average for tlue past ten years. The rôle played by the law and the legal profession in this development will now be examined.

The statutes of Nevada Territory relative to divorce received no legislative attention, and no change in them was made between 1861 and 1913. At the outset, it may be well to point out that the recognized grounds for divorce even today in o Nevada furnish nothing novel or scandalous in the way of marital grievances that may sanction a dissolution of the relationship, nor any ground for divorce that is peculiar to this state. It was the short period of residence required which made the Nevada law unique and paved the way to its subsequent development-and especially

- The Trial of Earl Russell (Before the King in Parliament) [1901] A. C. 446. A prior English statute (Offenses against the Person Act, 1861, $24 * 25$, Vicr., c. 100, 557) had extended the offense of bigamy to include cases where the second marriage took place outside of England.

- The grounds for divorce in Nevada are the following:

NEv. CoNp. Laws (Hillyer, 1934 Supp.) \$9460:

First-Impotency at the tirse of the marriage continuing to the time of the divorce.

Second-Adultery since the marriage, remaining unforgiven.

Third-Willful desertion, at any time, of either party by the other, for the period of one year.

Fousth-Conviction of felony or infamous crime.

Fifth-Habitual gross drunkenness contracted since marriage, of either party, which shall incapacinte such party from contributing his or her share to the support of the family.

Sixth-Extreme cruelty in either party.

Seventh-Neglect of the husband, for the period of one year, to provide the common necessaries of life, when such neglect is not the result of poverty on the part of the husband which he could not aroid by ordinary industry.

Eighth-Insanity existing for two years prior to the commencement of the action.

Id. 5946;.06: When the husband and wife have lived apart for five consecutive years withour cohabitation the court may at its discretion grant an absolute decree of divorce at the suit of either party. 
to the practice under it-to a point where it may be said that today divorce may be had in Nevada by mutual consent and with an absolute minimum of strain on anything but the conscience. It is this feature, then, that has resulted in the commercialization of the divorce business and has placed Nevada in the unenviable light of permitting itself to be a party to the subversion of the laws of her sister states solely for the gain to be derived therefrom and not because of any altsuistic motives.

The possibilities of the six months provision with respect to residence lay undiscovered for almost fifty years, and, like most opportunities, it was quite by accident that its advantages were disclosed and the application of them in magnitude vaguely conceived. In Igog, a lawyer who had removed to Nevada from New York perceived the potentialities of a profitable exploitation of our divorce law and proceeded to inaugurate an advertising campaign in New York with much success. The states of New York and New: Jersey have been the origin of about 60 per cent of the divorce business in Nevada since that date. At that time, however, the people of Nevada generally recognized the undesirability of such traffic and reprehended the conduct of the legal profession in commercializing divorces. Disbarment proceedings were brought against this attorney, and he was suspended from practice, although not because he advertised the amenities of the Nevada law but because of his violation of professional ethics in advertising for business for himself in connection therewith.

The additional publicity attending these proceedings advertised the law still further. Other attorneys assisted in carrying on this publicity but with more circumspection. The divorce traffic grew in consequence, and as it grew the profitableness of it to the lawyers, tradesmen, hotel men, and others became so clearly evident that their approval and active support were gained. Reno, being the metropolis of Nevada, got practically all the business, and it thrived immensely. In Igro its population was 10,867; in 1920, 12,016 ; and in 1930, 18,529 . How much of this increase is due to the divorce business it is impossible to say, but certainly it is a very heavy contributing factor.

The unfavorable publicity given the State by reason of this growing traffic was not relished by most of the other sections of the State where its pecuniary benefits had not become tangibly felt and whose morality therefore was not put to a strain. This led to an amendment of the law in IgI3 to deny jurisdiction to the courts in those actions in which the cause for divorce had not accrued within the State unless either the plaintiff or the defendant had been a bona fide resident of the State for one year next preceding the commencement of the action. ${ }^{\circ}$ In 1915 the legislature restored the six months' residence provision and left out the phrase "bona fide," with evident design it seems. But the State Supreme Court, however, has continued to

' In re Schnitzer, 33 Nev. 581, 112 Pae. 848 (1912).

- Presson v. Presson, 38 Nev. 203, 147 Pac. Io8r (1915); Walker v. Walker, 45 Nev. 105, 198 Pac. 433 (1921); Latterner v. Latterner, 51 Nev. 285, 274 Pae. 194 (1929).

'Nev. Stat. 2915, p. 26. 
read these words into the statute, ${ }^{3}$ thereby obliging the lower courts and the legal professsion to rub them out by a convention in perjury which will hereafter be more fully explained.

The business seemed large and lucrative and was so featured and exaggerated by the press of the nation that it came to be the national belief that Nevada had in the divorce business an asset exceeding that of her mines of gold and silver. When we consider; however, that it was largly localised in a comparatively small community, all handled by a group of about 120 attorneys, and by many of these as a side-line, it can be readily appreciated that the business was really insignificant, so that if it were spread over a state with a larger population and among many cities its pecuniary benefits would be unnoticeable. It is because of this localization that Nevada probably never will have a serious rival. When you have such centralisation that two judges and 120 lawyers handle about go per cent of the Nevada divorses, local and foreign, a closely-knit organization is the result, which operates with the ease, precision, and speed of an ingenious machine. Presently we will take this mechanism apart and exhibit and explain the construction and function of its separate parts.

The lawyers came to believe that if the residence period were cut in half the business would be greatly stimulated and might increase many times in volume. This potential multiplication proved attractive, and, with the backing of the business interests, an amendment reducing the residence period to three months was jammed through the legisiature in the last minutes of its protracted session in $19270^{\circ}$ The new law operated to favor the interests of the lawyers and others whose profits depended on volume of business but to the disadvantage of the interests of business generally. The number of divorce suits filed under the new law a little more than doubled, and clients therefor were more than twice as many. Not so with business. It found that more than twice the number of people sojourning for but half the former time did not produce even an amount of expenditure by the colony equivalent to that under the six months law. Wardrobes needed less replenishing, automobiles fewer renewals and repairs, and other items of consumption were similarly affecied.

Not a few people who were required to remain in Nevada for a period of six months had time to get acquainted with the state and its people., The salubrity of the climate and the beautifully contrasting scenery, of desert and valley, mountain, piain, and lakes afforded a never-failing sense of the grandeur of nature and the dignity of man. The friendliness, informality, and tolerance of our people was as broad and as unconfined as their domain, and these together induced many to remain as permanent acquisitions.

Other states came to envy the monopolization by Nevada of such a lucrative buşiness, and competition unsheathed its sharpened claws. In a frenzied attempt to head off this threatened rivalry, the legislature in its $193 \mathrm{I}$ session reduced the period of residence to six weeks, the act becoming effective May r, 1931. ${ }^{10}$

\footnotetext{
-Walker v. Walker, 45 Nev. 105, 198 Pac. 433 (I921); Latterner v. Latterner, 5r Nev. 285, 274 Pac. 194 (1929).

Nev. Stat. 1927 , p. 126.

${ }^{20}$ Nev. Stat. $893 x$, p. $16 x$.
} 
The only important changes in the substantive law of divorce in Nevada since 186x aside from the residence requirements were in 1927 when "Insanity of the defendant for two years" was added as a ground; ${ }^{11}$ in 1931 when the doctrine of Comparative Rectitude was adopted, ${ }^{12}$ and, in the same year, when separation of the spouses for five years without cohabitation was established as an additional ground, ${ }^{18}$ offering to those who had themselves dissolved the marital status in fact, a legal dissolution by law.

On the procedural side, however, considerable has been done by the legislature to remove most of the asperities of the law and what it has not accomplished, the ingenuity of the legal profession and the amiable inclinations of the judges have attained in the development of a technique that defies duplication in a less circumscribed environment. The struggle between the conservatism and traditions of the judiciary on the one side and the efforts of legislature, lawyers, and business on the other to establish by one means or another a system that would be speedy, painless, and profitable, without loss of dignity and respectability, has ended in the victory of the latter in the eyes of the world, if not in the eyes of many Nevadans.

The jurisdiction of the court is, of course, based upon residence for the required period by one or both parties and sarvice of summons on, or appearance by, the defendant. The period for answering has been reduced from 40 to 30 days when the defendant is served outside the district of the court. ${ }^{14}$ Where appearance by the defendant cannot be secured or personal service of summons obtained, it is necessary to resort to substituted service by publication. The period of publication has been shortened from six weeks to four. ${ }^{15}$ The result of these changes, all induced to favor the divorce business, is that a plaintiff may secure a divorce on the forty-third day if the defendant will enter an appearance by a Nevada attorney. This period is extended to seventy-three days, plus whatever time is consumed in securing service of summons, when voluntary appearance can not be obtained, and to one hundred and two days when publication is the necessary resort. The plaintiff must be actually present in the State for forty-two days before suit can be instituted. . This is in concession to the interests of the business group, and it is rigidly enforced by the requirement of a statute prescribing that the party's. testimony on this subjoct must be corroborated. ${ }^{16}$

We may observe here that this is the only respect regarding which corroboration is required. The court will accept the uncorroborated testimony of the plaintiff as to almost impossible situations touching the married life of the parties, but in respect to that forty-two days in Nevada, the plaintiff's testimony is not trusted and accord-

2 Ner. Stat. 1927, p. 126 .

${ }^{21}$ Nev. Stat. 1931, P. 179, Nev. Costr. Lnws (Hillyer, r934 Supp.) \$9467.01: In any action for divorce when it shall appear to the court that both husband and wife have been guilty of 2 wrong or wrongs, which may constitute grounds for 2 divore, the court shall not for this reason deny a divorce, but in its discretion may grant a divorce to the party least in fault.

22 See note 4, supra.

${ }^{2}$ NEv. Co20. Luws (Hillyer, 3934 Supp.) 58583. The earlier provision was repealed by Nev. Stat. 293x, P. 14. 
ingly a local resident must be brought in to clinch the matter. The legislature, in - enacting this requirement, did not pretend to reflect on the climate of Nevada or its scenery by expressing its opinion that it was so inherently improbable that anyone would remain in Nevada for even so short a period that the proof must be absolutely convincing. If, due to the refusal of the defendant to enter an appearance, the case does not mature in forty-three days, the additional time elapsing to maturity may be utilized outside the state for periods varying with what the particular judge may feel is a proper concession to the requirements of bona fides. Bona fides is getting less and less attention right along, and even today on a proper showing, which resourceful counsel can make out of seanty material, it may be arranged that the plaintiff need not be in the state on the day of hearing, his deposition being used instead. This exemplifies how everything is being shaped to attain the utmost in convenience and accommodation to the divorce seeker, until it soon may be said that the divorce and not the seeker is migratory in character. Laws and judicial conventions are gradually being broken down by the irresistible pressure of economic forces.

While we are on the subject of bona fides it may be well to conclude it. So far as the writer is advised, it appears that the courts everywhere require more than 2 lip service to the rule of bona fides in the establishment of residence conferring jurisdiction. In Nevada it is entirely disregarded in some respects; in others the surrender is incomplete. As an illustration, the usual formula is for the plaintiff to testify in answer to leading questions that he came to Nevada for the purpose of making it his home and place of residence for an indefinite period of time, and that such intention still abides with him. The actual state of the record perhaps is that he had filed his case on the same day, the forty-third, of his residence.

It may be a matter of common knowledge that his home and his buisiness are in New York, but no specific questions are asked as to why he left New York and came to Nevada and filed his case by the stop-watch. The courts have no hesitancy in accepting this general statement as establishing the good faith of his residence, and yet, had his case been one which had necessarily detained him in Nevada beyond the forty-three days-as it has in some cases for several months-his absence during any part of that period has been, and is today (yet with more sympathetic consideration), solemnly considered as being relevant-as indeed it is-to the bona fides of the residence. It is quite generally believed by lawyers that the court must find the residence bona fide in order that the decree may be recognized by other states, so in deference to this view the plaintiff must in most cases commit a perjury, counsel must connive at it, and a temple of justice must solemnly wink at it. One judge, with the idea of correcting this situation regardless of its extra-territorial consequences, held in a case that the plaintiff had actually resided in the state for the requisite time but that such residence had not been shown to be bona fide. On appeal, the Supreme Court of the State, held that, notwithstanding the legislature of $19 \times 3$ and subsequent ones had discontinued the use of the phrase "bona fide," and 
notwithstanding the prevalent practice and international reputation of Nevada as a trafficker in divorce, a bona fide residence must be proved. ${ }^{27}$

Other features of Nevada divorce law and practice; illustrative of the adaptation of the machinery of divorce to the desires of the divorce seeker, which it will suffice merely to mention without comment, are the following:

(1) In order to expedite the action, the defendant, contemporaneously with the filing of the complaint, is permitted to file an answer which usually denies only the truth of the grounds alleged for divorce in order to make an issue. This is accom: panied by a stipulation, usually oral, that the issue may be tried immediately.

(2) A statutory rule of pleading that permits "cruelty" to be alleged generally, with the right of the defendant, in the event of a genuine contest, to call for a "Bill of Particulars" enumerating the specific acts of cruelty on which the plaintiff will rely. ${ }^{18}$

(3) The statutory exclusion of all but the pleadings from the record of the case open to the public. ${ }^{10}$

(4) A statute requiring the court to close the court-room doors to the public and for a hearing in camerc at the request of either party. ${ }^{20}$

(5) The statute permitting a default case to be reopened and the defendant to enter a general appearance for the purpose of having the record show jurisdiction over the parties by a nunc pro sunc judgment.22

Notwithstanding the amenability of the judges to the administration of the law unfettered by a too serupulous regard to its letter, they have their individual peculiarities like other people. Some are more strict in certain respects than others. The residence of the plaintiff is not required by the law to continue for any preseribed period in the county where suit is brought, and it may happen that the judge who would ordinarily hear the case in the county of the plaintiff's residence, may be deemed by counsel iess desirable in the particular case than a judge in some other county. In this case counsel takes his client into another county where he feels less apprehensive of embarrassment, permits the client to gain a residence in that county by sitting in the automobile while the papers are being filed, and immediately thereafter has the case heard and disposed of.

This weapon has been a most potent one to discipline judges even who have endeavored to be conscientious. To shun a judge's court under local conditions is not only to insult him subtly but to break his spirit and schedule him for retirement. Usually he capitulates rather than be looked upon as a destroyer of business. If so, another refinement is added to the practice, or at least its spread over a wider area of the state is secured, until finally it becomes a part of the large body of the unwritten law of procedure which has contributed so much to give Nevada her preeminence in the migratory divorce business.

\footnotetext{
${ }^{19}$ Latterner v. Latterner, supra note 8.

2N Nev. Comp. Laws (Hillyer, I934 Supp.) 59467.04 .

20. 1 . 59467.03 .

Id. \$9467.0s.
}

Id. 59488. 